\title{
HAEMOLYSIS AND REVERSIBLE AGGLUTINATION OF TRYPSINIZED NORMAL RED CELLS BY A NORMAL HUMAN SERUM
}

\author{
BY \\ T. H. HURLEY AND J. V. DACIE \\ From the Department of Pathology, Postgraduate Medical School of London
}

(RECEIVED FOR PUBLICATION DECEMBER 18, 1952)

Morton and Pickles (1947) demonstrated the agglutination of trypsinized normal red cells (T.N.C.) by sera containing incomplete anti-Rh. The value of T.N.C. in the detection of antibodies of this type has since been confirmed, and it has also been established that these enzyme-treated cells are agglutinated by the antibodies present in the sera of cases of acquired haemolytic anaemia (Wheeler, Luhby, and Scholl, 1950; Dacie and de Gruchy, 1951; Rosenthal, Dameshek, and Burkhardt, 1951). Trypsinized normal red cells are also agglutinated by cold antibodies to a higher titre than are normal red cells (Bouroncle, Dodd, and Wright, 1951). In 1951 Rosenthal and Schwartz (1951a and b) reported that T.N.C. might be agglutinated at $37^{\circ} \mathrm{C}$. by normal sera at dilutions of up to 1 in 32 . However, this agglutination was observed only if the suspension of T.N.C. in the test serum was centrifuged immediately after mixing. They also reported that such agglutination would disperse on further incubation at $37^{\circ} \mathrm{C}$. Rosenthal and Schwartz's observations have been confirmed by Spaet and Ostrom (1952), who also showed that the reversal of agglutination was accompanied by elution of the agglutinin and that this took place more rapidly in serum than in saline.

We describe in the present paper the occurrence of an agglutinating factor probably similar to the type described by Rosenthal and Schwartz, but present in high concentration and capable of causing lysis of T.N.C. This factor has been demonstrated in the serum of a patient $C$, aged 72 , blood group $\mathrm{O} R \mathrm{Rh}$ positive, originally suffering from pernicious anaemia, who at the time of examination was in complete remission as a result of treatment with vitamin $B_{12}$. Her general health was good except for hypertension of moderate degree, and the presence of the factor was detected when her serum was used as one of a series of normal controls in a previous investigation (Dacie and de Gruchy, 1951).

\section{Materials and Technical Methods}

Patient's Serum.-This was obtained from blood defibrinated at room temperature. Fresh serum and 16 samples of serum collected over a period of 18 months and stored at $-20^{\circ} \mathrm{C}$. were all found to contain the agglutinating factor in practically similar concentration.

Technical Methods. - Crystalline trypsin (Armour) was used; its method of use and other routine methods were identical with those employed by Dacie and de Gruchy (1951). Three additional reagents were employed:

Antiglobulin Serum Neutralized with Gamma Globulin.-Volumes of anti-human globulin rabbit serum (diluted 1 in 4 in saline) were neutralized or partially neutralized by the addition of equal volumes of a serially diluted solution of human gamma globulin (Dacie, 1951). The neutralized or partially neutralized antiglobulin serum was then tested for its ability to agglutinate corpuscles sensitized by the patient's agglutinating factor.

Vibrio-treated Normal Red Cells.-These were prepared by the method of Stewart (1949). Equal volumes of a $50 \%$ suspension of normal red cells and the supernatant obtained by centrifugation of a broth culture of Vibrio sp. (N.C.T.C. 4711) were incubated together for one hour at $37^{\circ} \mathrm{C}$. The cells were then washed several times in normal saline.

Periodate-treated Normal Red Cells.-These were also prepared by the method of Stewart (1949). Equal volumes of $\mathrm{M}-100$ potassium periodate in saline and a $50 \%$ suspension of washed normal red cells were allowed to react at room temperature for half an hour. The cells were then washed in two changes of normal saline. 


\section{Results}

Specificity.-The serum of patient $\mathrm{C}$ was found to agglutinate, and to haemolyse, and to sensitize strongly to antiglobulin serum T.N.C. from a large number of compatible group $\mathrm{O}$ human bloods irrespective of Rh, MN, S, Kell, Lutheran, Lewis, and Duffy types. It was also found to be equally active against the patient's own cells if these were trypsinized. It failed to agglutinate, haemolyse, or sensitize untrypsinized compatible normal human corpuscles or the corpuscles from a patient with paroxysmal nocturnal haemoglobinuria. A direct antiglobulin (Coombs) test carried out on the patient's cells was negative.

Thermolability and the Role of Complement.The factor was found to be thermolabile and completely destroyed by heating at $56^{\circ} \mathrm{C}$. for 10 minutes; on the other hand, its activity was almost unimpaired after heating at $50^{\circ} \mathrm{C}$. for 30 minutes. The activity of the heated serum was not restored by the addition of fresh normal human serum. However, it was shown that the addition of fresh normal serum increased the amount of lysis caused by patient's serum stored for 21 months at $-20^{\circ} \mathrm{C}$. It was thought likely that this effect resulted from the addition of complement, but this was not proved to be so. The addition of fresh normal serum did not enhance agglutination or increase the degree of sensitization to antiglobulin serum caused by stored patient's serum.

Effect of pH.-Lysis, agglutination, and sensitization to antiglobulin serum were found to take place only within the restricted $p \mathrm{H}$ range of 6.6 to 8.5 approximately.

Reversibility of Agglutination.-The serum of patient $\mathrm{C}$, when diluted in normal human serum, haemolysed T.N.C. at a final serum dilution of
1 in 16 or less. Under these circumstances no macroscopic agglutination was visible; however this could be demonstrated by microscopy or byc immediate centrifugation. In saline agglutination $\frac{\overline{5}}{\mathrm{~s}}$. took place in final serum dilutions of 1 in $256 \sigma_{\bar{\sigma}}^{-}$ or less without recourse to centrifugation. Agglu응 tination, once produced, dispersed on further in cubation at $37^{\circ} \mathrm{C}$. (Table I). This dispersa 5 was accelerated by the presence of normal humanserum and was complete within 30 minutes; itw. was far slower in saline. Dispersal of agglutinae tion proceeded less rapidly in normal humanp serum heated at $56^{\circ} \mathrm{C}$. for 30 minutes than it did in unheated serum, but more rapidly than it dio in saline. The rate of dispersal of the agglutina $=$ tion in normal serum was independent of $p \mathrm{H}$ - within the $p \mathrm{H}$ range 6.0 to 8.5 ; it was appreciably slower at $25^{\circ} \mathrm{C}$. than at $37^{\circ} \mathrm{C}$.

During the phase of agglutination the concentrae tion of the agglutinin in the supernatant serump fell ; it rose again with dispersal of agglutination $\vec{c}$ Once agglutination had dispersed, it could not be्य reproduced by centrifugation. If, however, the dispersed cells were washed several times in salines and resuspended in either the original supernatants or in fresh dilutions of the patient's serum, aggluo tination was found to take place once more.

Cross-reactions with Vibrio-treated Norma Red Cells.-The patient's serum failed to agglutio $\overrightarrow{0}$ nate to a greater degree than did samples of nor mal sera normal red cells treated with Vibrio It did not seem possible to absorb the antibody out of samples of the patient's serum with sus? pensions of Vibrio-treated normal red cells.

Cross-reactions with Periodate-treated Normar. Red Cells.-The patient's serum also failed to̊ agglutinate periodate-treated normal red cells to an appreciably higher titre than did normal sera? Absorption with T.N.C. did not remove the

TABLE I

THE AGGLUTINATION OF TRYPSINIZED NORMAL RED CELLS (T.N.C.) BY PATIENT C'S SERUM

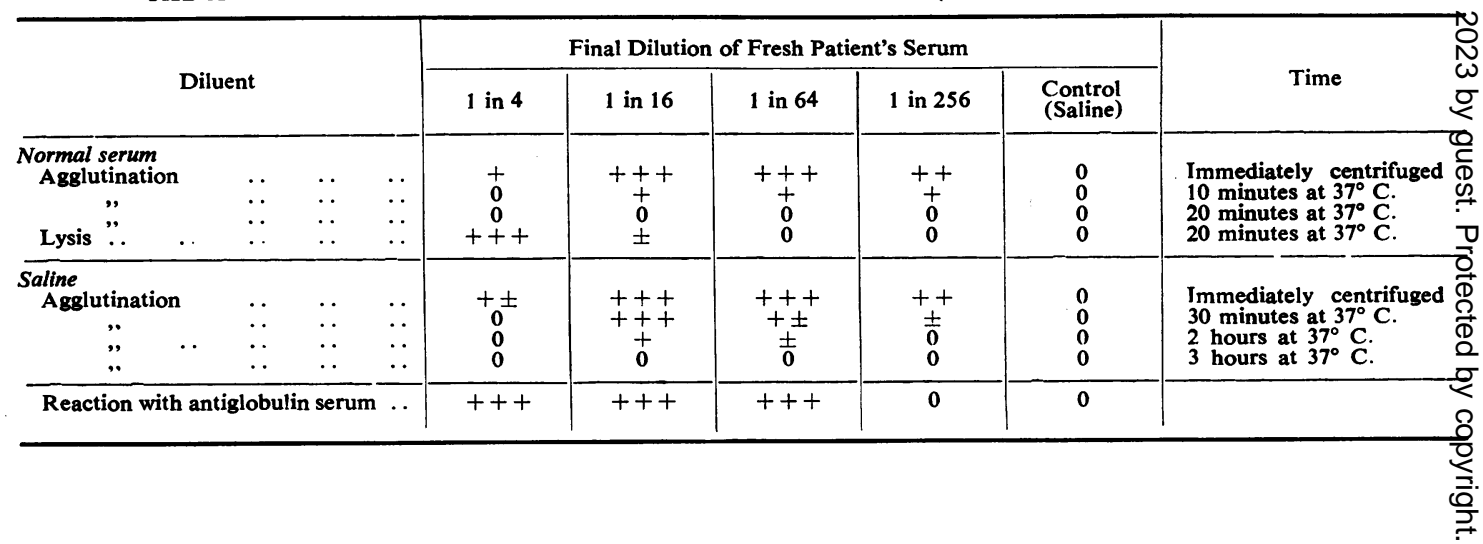


periodate-treated normal red-cell agglutinating factor.

Agglutination by Antiglobulin Serum.-When T.N.C. were agglutinated by the patient C's serum at $37^{\circ} \mathrm{C}$. and the agglutination allowed to disperse as a result of further incubation, the cells were then found to be strongly agglutinated by antiglobulin serum after washing in two changes of a large volume of saline (Table I). This agglutination was hardly affected by the previous addition to the antiglobulin serum of gamma globulin (Dacie, 1951). Trypsinized normal red cells incubated at $37^{\circ} \mathrm{C}$. with sera from normal controls were also found to be agglutinated by anti-human globulin serum subsequently. However, the intensity and titre of agglutination were far less than with the patient's serum.

\section{Discussion}

The observations outlined in this paper provide additional information on a factor which reacts with trypsinized normal red cells and which is present in low concentrations in most, if not in all, normal sera. It is now clear that this factor may occasionally be present in high concentration in the serum of an apparently normal subject, and that it is capable of lysing T.N.C. and also of sensitizing the cells to antiglobulin serum. The factor is active within an unusually restricted $p \mathrm{H}$ range, and appears to be thermolabile. Lysis is thought to take place only in the presence of complement.

Our findings suggest that the factor present in patient C's serum is similar to that detected in normal sera in relatively low concentrations by Rosenthal and Schwartz (1951a and b). The differences between our patient's serum factor and that present in other normal sera-namely, its ability to lyse T.N.C. and to agglutinate them in high dilutions in saline without centrifugationare probably due to its unusually high concentration in the serum of our patient.

The failure of the patient C's serum to agglutinate or sensitize Vibrio- and periodate-treated normal red cells at abnormal titres and the failure of these modified cells to absorb the T.N.C.-reacting factor suggest that the latter is distinct from the factors agglutinating Vibrio-treated and periodatetreated normal red cells respectively. This conclusion is in accord with the previous observations of Stewart (1949) and Moskowitz and Treffers (1950), which demonstrated the antigenic specificity of Vibrio- and periodate-treated nor- mal red cells, and with those of Stewart and Meenan (1951), which suggested a difference between the action of trypsin and Vibrio on the agglutinability of red cells.

A remarkable feature of the results described by us is that T.N.C. exposed to the patient's serum were strongly agglutinated by antiglobulin serum, despite the fact that most, if not all, of the agglutinin initially adsorbed by the cells was eluted on further incubation into the supernatant serumsaline dilution. Two explanations of this apparent anomaly seem possible. One possibility is that the elution of the factor is incomplete and that enough remains adsorbed on the cells for them to be strongly agglutinated by antiglobulin serum. Alternatively, the agglutination by antiglobulin serum might conceivably result from the adsorption of normal serum protein due to damage to the cell surfaces resulting from the initial phase of agglutination. Some evidence in favour of the first hypothesis was obtained by absorbing the patient's serum with packed T.N.C. Using fresh T.N.C. factor, it seemed as if most, but not quite all, of the sensitizing was eluted on prolonged incubation.

As already mentioned, patient C's serum factor was picked out of a series of control sera by Dacie and de Gruchy (1951), who were investigating the reactions of sera obtained from patients suffering from acquired haemolytic anaemia with T.N.C. Patient C's serum was remarkable in that it caused rapid lysis of T.N.C.; 105 other control sera caused neither lysis nor agglutination by the method used (two hours' incubation at $37^{\circ} \mathrm{C}$.). Nine sera from patients with acquired haemolytic anaemia agglutinated T.N.C. at $37^{\circ}$ C. ; six sera caused lysis in addition. It should be stressed that the agglutination of T.N.C. brought about by the antibodies of acquired haemolytic anaemia is not reversible on further incubation; after 24 hours at $37^{\circ} \mathrm{C}$. it is as strong if not stronger than after two hours' incubation. The two types of agglutinating factors are believed to be unrelated.

\section{Summary}

A description is given of a factor present in high concentration in the serum of an elderly woman which reacted with trypsinized normal red cells, but not with unmodified red cells. Lysis, agglutination, and sensitization to antiglobulin serum resulted.

The agglutination was reversible, the rate of reversibility being increased by the presence of normal human serum. 
The agglutinating factor appears to be distinct from the agglutinins reacting with Vibrio-treated red cells and with periodate-treated red cells, respectively : it is probably similar, except in respect of concentration, to the factor described by Rosenthal and Schwartz as being present in most normal sera in low concentration. The factor is quite distinct from the antibodies of acquired haemolytic anaemia which cause irreversible agglutination of trypsinized normal red cells.

\section{REFERENCES}

Bouroncle, B. A., Dodd, M. C., and Wright, C.-S. (1951). J. Immunol., $67,265$.
Dacie, J. V. (1951). Lancet, 2, 954.

and de Gruchy, G. C. (1951). Journal of Clinical Pathology, 4, 253.

Moskowitz, M., and Treffers, H. P. (1950). Science, 111, 717.

Morton, J. A., and Pickles, M. M. (1947). Nature, Lond., 159, 779.

Rosenthal, M. C., Dameshek, W., and Burkhardt, R. (1951). Amer. J. clin. Path., 21, 635. - and Schwartz, L. I. (1951a). Proc. Soc. exp. Biol. N.Y., 76, 635. (1951b). Fed. Proc., 10, 332.

Spaet, T. H., and Ostrom, B. W. (1952). Journal of Clinical Pathology, 5, 332.

Stewart, F. S. (1949). J. Path. Bact., 61, 456.

and Meenan, P. N. (1951). Irish J. med. Sci., 6th series, No. 311, p. 541 .

Wheeler, W. E., Luhby, A. L., and Scholl, M. L. L. (1950). J. Immunol., 65, 39. 